\title{
Different Characters and Destines of Four Sisters in Little Women
}

\author{
JING Jing \\ Changchun University, Changchun, China
}

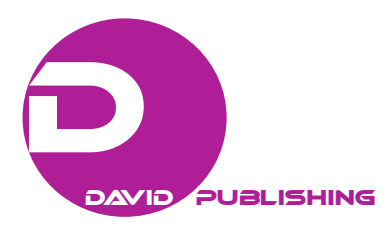

\author{
JING Xia \\ No. 20 Junior Middle School of Siping, Siping, China
}

\begin{abstract}
Little Women is a novel published in1868 and written by American author Louisa May Alcott. The story concerns the lives and loves of four sisters growing up during the American Civil War. It was based on Alcott's own experiences as a child in Concord, Massachusetts with her three sisters, Anna, May, and Elizabeth. It is a story about love, faith, fortitude, and devotion. And this paper aims at analyzing the four sisters' different characters and destinies and tries to give readers a new understanding about this novel.
\end{abstract}

Keywords: characters, destines, Little Women

\section{Introduction}

Little Women is written by American author Louisa May Alcott. And the story of the Marches happened in Massachusetts during the American Civil War. It includes most problems which probably happen in the growth of four sisters, such as the problems in first love, friendship between teenagers and the gap between the dream and the reality. Learned from the growth story of four sisters, we find that the four sisters are different. They have different characters, hobbies, thoughts, and personalities, and at last they have different lives, results, and destinies. Although Father March is away with the Union armies, the sisters Meg, Jo, Amy, and Beth keep in high spirits with their mother, affectionately named Marmee. Jo is creative and love writing. Meg is noble, vain, and love writing plays, acting, and housekeeping. Beth has the spirit of sacrifice, and love playing the piano. Amy is graceful and selfish, and love painting. However, despite their efforts to be good, the girls show faults: The pretty Meg becomes discontented with the children she teaches; boyish Jo loses her temper regularly; while the golden-haired schoolgirl Amy is inclined towards affectation. However, Beth, who keeps the house, is always kind and gentle. Maybe their different characters decide their different destinies.

\section{Jo's Characters and Destiny}

When we first meet Jo March, she's a tomboyish, hot-tempered, geeky fifteen-year-old girl. She loves activity and can't bear to be left on the sidelines; it drives her crazy that she can't go and fight in the Civil War alongside her father, who has volunteered as a chaplain. Instead, Jo has to stay at home and try to reconcile herself to a nineteenth-century woman's place in the domestic sphere, which is extremely difficult for her. You can hear the trouble in her name- she's called Josephine, a feminine name, but she goes by the more masculine-sounding Jo. She's clumsy, blunt, opinionated, and jolly. Her behavior is often most unladylike—she swears (mildly),

JING Jing, Master, Lecturer, School of Foreign Languages, Changchun University. JING Xia, Bachelor, Lecturer, No. 20 Junior Middle School of Siping. 
burns her dress while warming herself at the fire, spills things on her only gloves, and barely tolerates her cranky old Aunt March. She's so boyish that Mr. March has referred to her as his "son Jo" in the past, and her best friend Laurie sometimes calls her "my dear fellow".

Jo also loves literature, both reading and writing. She composes plays for her sisters to perform and writes stories that eventually were published. She imitates Dickens and Shakespeare and Scott, and whenever she's not doing chores she curls up in her room, in a corner of the attic, or outside, completely absorbed in a good book.

Jo hopes to do something great when she grows up, although she's not sure what that might be—perhaps writing a great novel. Whatever it is, it's not going to involve getting married; Jo hates the idea of romance, because marriage might break up her family and separate her from the sisters she adores.

As you might have guessed, Jo is being set up for a Meaningful Journey of Self-Discovery and Surprises. By the end of the novel, her dreams and dislikes are going to be turned topsy-turvy; her desire to make her way in the world and her distaste for staying at home will be altered forever. She may not find romance in the places that readers expect, but she will find it. She'll also realize that romantic love has its place, even though it changes the relationships you already have. As Jo discovers her feminine side, she also figures out how to balance her ambitious nature with the constraints placed on nineteenth-century women. These constraints reflect the contemporary situation of twenty-first-century women readers.

\section{Meg's Characters and Destiny}

Meg, short for Margaret, is the oldest and (until Amy grows up) the prettiest of the four March sisters. She's also the most typical of the sisters-we think of her as everything that you might expect a nineteenth-century American girl from a good family to be. Meg loves luxury, nice things, dainty food, and good society. She's the only sister who can really remember when her family used to be wealthy, and she feels nostalgic about those good old days. Her dream is to be wealthy once more and have a huge mansion with lots of servants and expensive possessions. She's also a bit of a romantic. When she has to tell a story to amuse her sisters, it's about love and marriage, and Jo starts to suspect pretty early on that Meg might have a real-life Prince Charming in her thoughts. Meg is sweet-natured, dutiful, and not at all flirtatious-in fact, she's unrealistically good and proper. Perhaps that's why she's so alarmed by her sister Jo's rambunctious, tomboyish behavior.

Each of the March sisters has at least one major character flaw that she struggles to overcome, and Meg is no different. Meg's problem is, well, avarice, greed, envy, wanting stuff that other people have. Whatever you call it, she's got it in spades. Meg tries to set aside her materialism, and gradually learns to value simple things more because of the hard work that it takes to earn them.

Before she gets to that point, however, she spends many, many hours envying the fortune and leisured life of her friends Sallie Gardiner and the Moffat girls. In fact, at one point Meg allows the Moffats to dress her up in fancy clothes, covering her in makeup and jewelry and making her show far more cleavage than a demure, Protestant, nineteenth-century girl really should. She even—we know you'll be horrified here-drinks champagne at one point! It only takes Meg one bout of this kind of vanity and wealth-worship to realize that the people she's trying to impress are unbelievably shallow. She doesn't feel like herself, and when she hears someone at the party say that she's dressed up like a doll, she realizes that's exactly what she's turned herself into, and she never does it again. Even at her wedding, Meg wears a simple dress that she makes herself by hand. 
Meg, the most traditionally feminine of the sisters, gets married. Her parents force her to wait until she is twenty before committing herself-an unusual step for parents of their time, but the Marches aren't typical in any way. But when Meg does marry, it's not to a wealthy man who can keep her in the style of a Moffat; it's too poor, hard-working, orphaned John Brooke. Meg and John don’t have much money, but they do have love. They also have something else that Meg's upbringing has taught her: the Protestant work ethic. Between these two qualities, they do just fine, and Meg soon fulfills the other function of a nineteenth-century woman: producing children. Her twins Daisy and Demi become the newest members of the March family.

We know we're being kind of flippant about Meg's decision to get married, have children, and be a stay-at-home mom and homemaker. We don't mean to suggest that we think this is an easy career path or a cop-out by any means - in fact, at some points in the novel, Meg seems to work the hardest of any of the sisters! The reason we're rolling our eyes is that it's just not a very surprising plot point. All young women in the nineteenth century were expected to get married, have children, and be housewives. In fact, there were very few careers in the public sphere open to women, and the girls who didn't get the chance to follow the same path as Meg were looked down upon. So, while we commend Meg for working hard, we have to look elsewhere in the novel for surprising plot twists.

A note about names: Margaret has two nicknames, "Meg” and "Daisy,” both of which were common nicknames for "Margaret" in the nineteenth century. This can be confusing at a few points, especially when Meg has a daughter of her own, names her Margaret, and calls her "Daisy.” We also learn that Meg's mother is named Margaret, too-maybe that's why she goes by Marmee, which sounds halfway between "Mommy" and "Margaret". So there are actually three Margarets, grandmother, mother, and daughter, but they’re usually referred to as Marmee or Mrs. March, Meg, and Daisy.

\section{Beth's Characters and Destiny}

Beth is one of those children in a novel who is so good and sweet and perfect that you just know she's going to die, because nothing interesting could ever happen to her, and anyone that angelic belongs in Heaven-like Little Nell in The Old Curiosity Shop or Eva in Uncle Tom's Cabin. OK, sorry if we spoiled that one for you, but seriously: Beth is happy and content at home, too shy to go to school or go out in the world, and spends her time doing sweet little things around the house to make her family, her pet cats, and even her dolls happy and comfortable. She's doomed. She has no ambitions, no desires, doesn't dream about getting married, and thinks about God and Heaven a lot. These are all the signs that a nineteenth-century author uses to tell you that a kid is not long for this world. The only thing that really surprises us is that she survives her first bout of scarlet fever and doesn't die until the second half of the novel.

Beth's only earthly love is music. She adores playing the piano and singing, and the only material thing that she wants is a nicer piano, since her family's is old and out of tune. The piano that she longs for is provided by her wealthy neighbor, old Mr. Laurence, who gives her his dead granddaughter's old piano. If you were still missing out on the signs that Beth is going to die, then you should get suspicious when you find out that Beth reminds Mr. Laurence of the little granddaughter he had who died young. Beth shares this anonymous girl's musical talent—and, by the logic of the sentimental novel, she's also going to share her early demise. Of course, Beth's love of music isn't that earthly, either. She mostly sings hymns, and her connection to such an ethereal art form 
also reinforces the idea that she belongs in Heaven, not in the parlor.

What we're trying to say is that Beth is the little-girl version of a nineteenth-century stock figure called the "angel in the house". The phrase "angel in the house" is the title of an 1854 poem by an author called Coventry Patmore (If you're keeping score, that means the poem came out fourteen years before the first part of Little Women, so it was definitely circulating in popular culture when Alcott's novel appeared). The poem itself is one of the few pieces of literature that we actually don't recommend-although you can read it here if you really want to-but basically it's about housewives, and how they should be these perfect, patient, personality-less, submissive domestic goddesses who make little safe nests for their hard-working hubbies and never, ever have opinions or needs of their own. The "angel in the house" figure defines everything that women were supposed to be in the latter half of the nineteenth century, and Beth, despite her youth and the fact that she doesn't get married, is definitely a sample of this tradition.

Just to be clear, we don't want to rag on housewives and other men and women who stay at home to take care of the family. The stay-at-home people we know work really hard and play a crucial role for their families and society. But, you know, we think they should be allowed to have opinions, and vote, and stuff, not just toss their curls and say "whatever you think, honey".

Anyway, back to Beth. Although she dies just as she reaches adulthood, Beth has a significant effect on the people around her, especially her sister, Jo. As Jo nurses Beth through her final illness, she realizes how important domestic duties really are. Jo resolves to take over Beth's role as the glue that holds her family together, caring for her parents and cherishing the everyday tasks that Beth did so lovingly. In this way, Beth's example lives on, although perhaps with a little more spice and a little less sugar.

\section{Amy's Characters and Destiny}

Amy is the March sister that most readers love to hate. She's the youngest of the family and she fits the stereotype of the spoiled youngest child. Amy's vanity begins with her appearance-she's a pretty child and turns into a beautiful, stately woman, with lovely golden hair and blue eyes. The only thing that bothers her is that her nose isn't quite aristocratic-looking enough-it's a little snub nose, instead of a stately Roman nose. You can bet that if Amy had lived in an era of plastic surgery, she'd have gone in for a nose job. As it is, she has to try to reshape her nose herself by wearing a clothespin on it while she's sleeping.

Amy's anxiety about her nose, however, is just the beginning of her obsession with all things upper-class. Amy's great ambition is to be a gentlewoman. She tries to make the most of her clothes and accessories, cultivates grace and politeness, and makes social calls on the family's wealthy friends and neighbors. She's pretty successful at it, too. Amy's interest in high society might be shallow, but her kind heart is deep, and people appreciate her classy behavior.

As a child, her ambitions seem ridiculous—she’s always misusing big words and affecting little snobby behaviors. Sometimes she even shows signs of a violent temper, such as when she burns one of Jo's manuscripts in revenge for being left at home while her sisters and Laurie attend a play. And she's also overly sensitive, possibly even spoiled — one punishment for breaking the rules at school is enough to make her resolve never to go back. But when she grows into a woman, Amy is far more genteel, and she's a big hit, both at home and abroad. 
In fact, it’s Amy's decorous behavior that convinces her Aunt to take her to Europe and her Aunt March to pay for the trip. Amy hopes to use her European adventure to cultivate and refine her artistic skills. From childhood on, Amy's tried every kind of visual art there is, from painting to sketching to sculpting. Most nineteenth-century young women dabbled in these arts, but Amy hopes to make a career out of them. In fact, she wants more than a career; she wants to do the work of genius. Eventually, Amy has to admit to herself that, while she's talented, she doesn't have that special extra inspiration that would mark her as a true artist. Instead, she contents herself with fashioning her life artistically.

It's easy for Amy to turn her focus from her art to her life when Laurie arrives in Europe and starts hanging out with her. Freed from the patterns of interaction that were set for them by the family dynamic back home, Amy and Laurie discover each other anew. Laurie realizes that Amy is exactly the kind of graceful, principled woman who would make a good wife for him, and Amy realizes that Laurie's strength and comfort mean more to her than anyone else's ever could. Sadly, this disrupts Amy’s plan to be a gold-digger and marry the wealthy Fred Vaughn for his money. But, as Marmee’s daughter, Amy was always destined to realize that love means more than money, and that respect is also important.

\section{Conclusion}

Sometimes, characters may decide people's destinies. Young people must have a great deal of help in forming their characters. They will not at first readily admit their weaknesses and faults. Adults should tell them when they are doing good things and when they are not. This is simply moral teaching or coaching. Ultimately, however, a person will have to take full responsibility for his own character. The great historian Macaulay defined character perhaps better than anyone. The measure of a man's character is what he would do if he knew he would never be found out. Every parent and teacher should put to young people this question: "What will you do when I am not looking over your shoulder?” In other words, those who cannot be trusted without being watched will never be entrusted with great things, just like the four sisters in Little Women.

\section{References}

Alcott, L. M. (2004). Little women. NewYork: New America Library.

Ann, B. M. (1990). The border of ethical, erotic, and artistic possibilities in "Little Women”. Chicago: The University of Chicago Press.

Barbara, S. (2010). Well read lives: How books inspired a generation of American women. Chapel Hill: The University of North Carolina Press.

Boyd, A. E. (2004). Writing for immortality: Women writers and the emergence of high literary culture in America. Baltimore: Johns Hopkins University Press.

Elbert, S. (1984). A hunger for home: Louisa May Alcott and Little Women. Philadelphia: Temple University Press.

Elbert, S. (1987). A hunger for home: Louisa May Alcott's place in American culture. New Brunswick: Rutgers University Press.

Eugenia, K. (1978). Louisa May Alcott: Success and the sorrow of self-denial. Women's Studies, 53.

Fetterley, J. (1997). Little Women: Alcott’s civil war. Nineteenth-Century Literature Criticism, 58. Detroit: Gale.

MacDonald, R. M. (1983). Louisa May Alcott. Boston: Twayne Publishers.

Madeleine, B. S. (1950). Louisa May Alcott. Norman: University of Oklahoma Press.

Madison, C. A. (1974). Irving to Irving: Author-publisher relations 1800-1974. New York: R. R. Bowker Company.

Matteson, J. (2007). Eden's Outcasts: The story of Louisa May Alcott and her father. New York: W. W. Norton \& Company.

Perkins, G., \& Perkins, B. (2002). The American tradition in literature (Vol. 2). New York: McGraw-Hill. 